heden in de kliniek, die nooit in het nadeel van de student mogen uitpakken. Voorts heeft de Americans with Disabilities Act het onbedoelde effect op het medisch onderwijs dat studenten niet op grond van een handicap ongunstig beoordeeld mogen worden. Ten slotte nemen studenten thans veel sneller hun toevlucht tot gerechtelijke stappen of zelfs fysiek geweld als hun toekomst in het geding lijkt.

Albanese roept op tot een "National Effort" om het tij te keren.

Th.J. ten Cate, Utrecht.

\section{Stress bij medisch studenten}

Niemi PM, Vainiomaki FT. Medical students' academic distress, coping, and achevenent strategies during the preclinical years. Teaching and Learning in Medicine 1999;11 (3):125-34.

Er is de afgelopen jaren veel gepubliceerd over stress bij medisch studenten. Dit onderwerp is van belang, omdat de hoeveelheid stress die studenten ervaren en de manier waarop zij er mee (leren) omgaan, invloed heeft op hun professionele houding. Waarschijnlijk is de houding tijdens de studie voorspellend voor de houding in het latere beroepsleven. Aan de Universiteit van Turku in Finland is bij een cohort studenten onderzoek gedaan naar stress en de verschillende manieren waarop studenten daar in de loop van de studie mee omgaan. De resultaten van de eerste twee en een half jaar van dit onderzoek (de preklinische fase) zijn onlangs gepubliceerd in een artikel. Een minderheid van de studenten had symptomen van stress, maar het aantal studenten met symptomen en de hoeveelheid stress namen beide toe in de loop van de opleiding. Er was een verband tussen de hoeveelheid ervaren stress en de strategie om ermee om te gaan. Bij de studenten die verschillende strategieën hanteerden, nam de hoeveelheid stress niet toe, terwijl dit wel het geval was bij de studenten die slechts één strategie toepasten. De auteurs stellen dat het een uitdaging voor docenten zou moeten zijn om studenten te stimuleren te reflecteren en voor henzelf geschikte manieren te ontdekken om met stress om te gaan.

Het is onbekend in welke mate de beschreven problematiek in onze onderwijscultuur een rol speelt. Bijdragen van onderzoekers die zich door deze vraag uitgedaagd voelen, zijn van harte welkom.

\section{A.J.J.A. Scherpbier, Maastricht.}

\section{Hoe academische vaardigheden in te bouwen en te toetsen?}

Filot A, Tenouw C. Academische voming als uitgangspunt woor curriculumontwerp. Thischift voor Hoger Onderwijs 1998;6(4):247-58. Moerkerke G. Toetsing van academische vadrdigheden: een curriculumperspectef Thidschifi woor Hoger Onderwijs 1998;16(3):178-94.

Academische vorming is een thema dat terecht centraal blijft staan in het hoger onderwijs. De actualiteit blijkt uit discussies over de studieduur en de dreigende verschoolsing van curricula. De ontwikkeling van de informatiemaatschappij en het toenemende belang van kennismanagement in het beroepsveld vragen echter om afgestudeerden met een brede academische ontwikkeling. Pilot en Terlouw geven suggesties hoe deze concreet in het curriculum in te bouwen. Academische vorming is vaak gebaseerd op algemene doelstellingen of taken van de universiteit en is te weinig gericht op het functioneren in werkveld en maatschappij. De auteurs formuleren enkele vragen om over dit begrip meer duidelijkheid te krijgen, waarbij zij academische vorming indelen in algemene functievereisten (wetenschapsgebonden, algemene beroepsgebonden en 
algemene persoonlijke bekwaamheden) en specifieke functievereisten (specifieke beroepsbekwaamheid en vertrouwd zijn met een bedrijfstak). De beschrijving van academische vorming moet de samenhang en integratie in het curriculum bevorderen, bijvoorbeeld in de vorm van competenties die worden opgenomen in leerimen, die de student systematisch en consistent stimuleren om zich gedurende het gehele curriculum academisch te vormen. Implementatie van deze leerlijnen is beter mogelijk in curricula waarin vaardigheden en integratie van kennisgebieden al een uitgangspunt vormen. Verder benadrukken de auteurs de veranderende taken en rollen van de docent. Het is essentieel dat docenten onderwijsonderdelen afstemmen en studenten over de grenzen van vakgebieden leren begeleiden en beoordelen. Tenslotte vragen de auteurs aandacht voor de uitwerking van innovatiecomponenten en het stellen van hoge eisen aan de organisatie van het innovatieproces om zorgvuldige invoering van academische vorming tot stand te brengen.

Moerkerke vraagt zich af hoe academische vaardigheden getoetst moeten worden en geeft daarmee een uitwerking op microniveau van de suggesties van Pilot en Terlouw. Hij pleit voor een skillsmanagementsysteem in het curriculum. Hierin wordt voor elke student regelmatig een persoonlibk profiel van academische vaardigheid opgesteld, bijvoorbeeld met behulp van " 3600 beoordeling". Dit is een portfolio met beoordelingen uit vier richtingen: van medestudenten, docent, het beroepsveld en de student zelf. Het persoonlijk profiel kan worden vergeleken met een gewenst profiel, waardoor tevens het leren kan worden bijgestuurd en integratie van toetsing en instructie plaatsvindt. De auteur komt tot een werkmodel waarin eindtermen, toetsfuncties en toetsvormen op elkaar zijn afgestemd. Daarin zitten vijf typen vaardigheden: materiedeskundigheid, probleemoplosvaardigheid, netwerkvaardigheid, zelfregulatie van professionele groei en zelfregulatie van commitment. Deze vaardigheden moet de professional volgens Moerkerke alle bezitten om als academicus te kunnen functioneren.

Melanie C.M. Ehren, AMC-UvA, Amsterdam.

\section{Luisteren naar monologen of naar dialogen?}

Fox The JE. Listening in on monologues and dialogues. Discourse Processes 1999;27 (1)/35-53.

Bij toeval stuit je soms op aardige vondsten. Hier betrof het een onderzoek op het terrein van de "Collaborative Theory of Communication". Deze theorie gaat ervan uit dat er een samenwerking tussen spreker en luisteraar bestaat om tot volledig begrip van de boodschap te komen. De spreker ontvangt signalen van de luisteraar, die begrip impliceren. Niet alleen door antwoorden, maar ook via hoofdknikjes en andere non-verbale signalen. De spreker kan daardoor zijn verhaal aanpassen aan de luisteraar en een beter effect sorteren. Uit onderzoek was al gebleken dat deelnemende luisteraars tot wie de spreker zich richt ("participating addressees”) meer oppikken dan luisteraars die buiten de communicatie staan (“overhearers"). Dergelijk onderzoek heeft praktische waarde voor het onderwijs. Denk aan de vraag of een boodschap beter in de vorm van een college, via video, informatie- en communicatietechnologie (ICT), schriftelijk of in een kleinschalige vorm kan worden overgebracht.

De onderzoeksvraag in dit artikel was of een "overhearer" boodschappen beter begrijpt en onthoudt, als er naar een monoloog of naar een dialoog wordt geluisterd. 